\title{
EKSISTENSI YURIDIS DAN EMPIRIS HUBUNGAN KERJA NON-STANDAR DALAM HUKUM KETENAGAKERJAAN INDONESIA $^{1}$
}

\author{
Nabiyla Risfa Izzati \\ Fakultas Hukum Universitas Gadjah Mada \\ Jl. Sosio Yustisia Nomor 1, Bulaksumur, Depok, Sleman, DIY \\ nabiylarisfa@ugm.ac.id
}

\begin{abstract}
This study examines the regulation of non-standard employment relationship in Indonesian labour law, and the impact of its workers' protection. The result of this study indicate that legally, the two types of non-standard employment relationship, namely temporary employment and multi-party employment relationship are regulated under Indonesian labour law. While the two other, which are part timelon-call work, and disguised employment/dependent selfemployment have not been regulated. However, empirical data shows that both part-time and gig economy workers (who can be categorized as disguised employment relationships) have existed for a long time, even increasing in number. The non-existence of regulations has caused the absence of legal protection for many workers under non-standard employment relationship in Indonesia.
\end{abstract}

Keywords: Gig Economy; Non-Standard Form of Employment; Temporary Employment; Part Time Work.

\begin{abstract}
Abstrak
Penelitian ini mengkaji pengaturan hubungan kerja non-standar dalam hukum ketenagakerjaan Indonesia serta dampaknya terhadap perlindungan hukum bagi pekerja. Menggunakan metode penelitian yuridis-empiris, hasil penelitian ini menunjukkan bahwa secara yuridis, terdapat dua bentuk hubungan kerja non-standar yang diatur dalam hukum ketenagakerjaan Indonesia, yakni hubungan kerja dengan sistem kontrak (PKWT) dan hubungan kerja outsourcing. Sedangkan, dua bentuk hubungan kerja non-standar lain, yakni hubungan kerja part-time atau on-call dan disguised employment relationship belum diatur dalam hukum ketenagakerjaan Indonesia. Padahal, secara empiris, data menunjukkan bahwa baik pekerja part-time maupun pekerja gigeconomy yang dapat dikategorikan sebagai disguised employment relationship telah lama eksis dan bahkan terus meningkat jumlahnya di Indonesia. Ketiadaan pengaturan ini berimplikasi pada absennya perlindungan hukum bagi banyak pekerja dalam hubungan kerja non-standar.
\end{abstract}

Kata Kunci: Gig Economy; Hubungan Kerja Non-Standar; PKWT; Pekerja Paruh Waktu.

\footnotetext{
${ }^{1}$ Hibah Penelitian Dosen Unit Riset dan Publikasi Fakultas Hukum UGM yang didanai oleh Fakultas Hukum Universitas Gadjah Mada pada tahun 2020.
} 


\section{A. Pendahuluan}

Diskursus hukum ketenagakerjaan tradisional pada awalnya hanya mengenal satu jenis hubungan kerja, yakni hubungan kerja yang bersifat standar. Hubungan kerja standar ini di Indonesia didefinisikan sebagai "hubungan antara pengusaha dengan pekerja/buruh berdasarkan perjanjian kerja, yang mempunyai unsur pekerjaan, upah dan perintah" sebagaimana diatur dalam Pasal 1 angka 15 Undang-Undang Nomor 13 Tahun 2003 tentang Ketenagakerjaan.

Hubungan kerja yang selama ini dikenal di Indonesia merupakan sebuah hubungan yang terjadi karena adanya perjanjian kerja antara pengusaha dan pekerja/buruh, yang memenuhi setidak-tidaknya 3 unsur, yakni: pekerjaan, upah, dan perintah (Darma, 2017; Hernawan, 2014). Menurut International Labour Organization (ILO), hubungan kerja standar ini memiliki tiga karakteristik utama, yakni: pekerjaan bersifat penuh waktu, pekerjaan bersifat tetap (bukan pekerjaan kontrak), dan pekerjaan dilandasi dengan perjanjian kerja (International Labour Organization, 2015).

Namun, perubahan situasi ketenagakerjaan di berbagai penjuru dunia melahirkan jenis hubungan kerja baru, yang sering disebut sebagai non-standard form of employment atau hubungan kerja tidak standar (Champeau, Arsac, Pineau, \& Denyset, 2016). ILO mendefinisikan nonstandard employment sebagai jenis hubungan kerja yang merupakan defiasi dari hubungan kerja pada umumnya. Hubungan kerja tidak standar ini kemudian dikelompokkan menjadi 4 jenis, yakni: a) Temporary employment; b) Multi-party employment relationship; c) Part time dan on-call work; dan d) Disguised employment/dependent self-employment. (International Labour Organization, 2015).

Dalam beberapa kasus, bentuk pekerjaan non-standar mengakomodasi perubahan-perubahan yang terjadi dalam pasar kerja. Namun di lain pihak terdapat berbagai tantangan yang muncul terhadap jenis-jenis pekerjaan non-standar, terutama yang berkaitan dengan perlindungan pekerja.
(Quinlan, 2015) Akhirnya, pekerja dalam hubungan kerja non-standar sering diasosiasikan sebagai pekerja yang rentan.(De Stefano, 2015; Market \& Group, 2002) Kebanyakan dari mereka bekerja dari satu pekerjaan jangka pendek ke pekerjaan jangka pendek yang lain sehingga lebih mudah mengalami Pemutusan Hubungan Kerja. Selain itu, pekerja dalam pekerjaan non-standar juga biasanya berpenghasilan lebih rendah dibanding pekerja tetap, dan kebanyakan dari mereka yang tidak terlindungi oleh jaminan sosial.

Jika dilihat dalam konteks Indonesia, pekerja dalam hubungan kerja non-standar sering dikategorikan sebagai pekerja informal. (Majanto, 2002; Midayati, 2018; Sari, 2016) Keempat jenis hubungan kerja non-standar sebagaimana kategorisasi dari ILO juga bukan merupakan hal yang asing di Indonesia. Namun, apakah hukum ketenagakerjaan Indonesia sudah mengakomodasi perlindungan hukum bagi pekerja-pekerja yang berada dalam berbagai skema hubungan kerja non-standar ini?

Kajian dari ILO tentang non-standard form of employment meyakini bahwa regulasi merupakan salah satu alat penting untuk mengamankan kondisi kerja pekerja yang bekerja dalam hubungan kerja nonstandar. (Champeau et al., 2016; International Labour Organization, 2015) Aturan hukum juga dapat dijadikan landasan penentu kapan dan seberapa sering hubungan kerja non-standar dapat digunakan. Karena itu, penelitian ini akan mengkaji mengenai pengaturan hubungan kerja non-standar dalam hukum ketenagakerjaan Indonesia, termasuk di dalamnya Undang-Undang Nomor 11 Tahun 2020 tentang Cipta Kerja yang baru saja disahkan, serta dampaknya terhadap perlindungan pekerja dan akses pekerja nonstandar terhadap hak-hak dasar pekerja.

Berdasarkan latar belakang yang telah dijabarkan dalam pendahuluan di atas, rumusan masalah yang akan dijawab dalam penelitian ini adalah: 1) Bagaimana eksistensi hubungan kerja non-standar (nonstandard form of employment) secara yuridis 
dan empiris dalam hukum ketenagakerjaan di Indonesia? dan 2) Bagaimana kaitan pengaturan hubungan kerja non-standard terhadap kelayakan bekerja bagi pekerjanya?

\section{B. Metode Penelitian}

Penelitian ini menggunakan metode penelitian hukum yang bersifat yuridisempiris. Secara umum, penelitian dilakukan secara bertahap, dengan tahapan pertama yakni studi kepustakaan dengan menggunakan sumber data-data sekunder, yaitu peraturan perundang-undangan terkait ketenagakerjaan, putusan pengadilan, teoriteori hukum, dan doktrin ahli hukum terkemuka.

Selanjutnya, penelitian empiris dilakukan melalui observasi terhadap keberadaan hubungan kerja non-standar dalam penyelenggaraan ketenagakerjaan di Indonesia. Penelitian ini juga melakukan studi empiris literatur, yang meliputi literatur akademik (buku, artikel jurnal), dan grey literatur (berita media masa, artikel online, laporan organisasi internasional, dan data penunjang lain). Metode analisis data yang digunakan dalam penelitian ini adalah metode kualitatif. Pendekatan yang digunakan adalah pendekatan undangundang (statute approach).

\section{Hasil dan Pembahasan}

\section{Eksistensi Hubungan Kerja Non- standar secara Yuridis dan Empiris di Indonesia}

Menurut ILO, hubungan kerja nonstandar dapat dikelompokkan menjadi empat kategori, yakni: a) Temporary employment; b) Multi-party employment relationship; c) Part time dan on-call work; dan d) Disguised employment/dependent selfemployment. Jika dilihat dalam konteks Indonesia, 4 jenis hubungan kerja nonstandar di atas tidak seluruhnya merupakan hal yang baru. Dalam subbab ini akan dianalisis satu persatu bagaimana eksistensi jenis-jenis hubungan kerja non-standar secara yuridis maupun empiris di Indonesia.

\section{a. Hubungan kerja waktu tertentu (temporary employment)}

Jenis hubungan kerja non-standar yang pertama adalah temporary employment atau hubungan kerja yang bersifat sementara. Hubungan kerja dengan jangka waktu sementara ini telah dikenal dan diatur dalam UndangUndang Nomor 13 Tahun 2003 tentang Ketenagakerjaan dengan istilah Perjanjian Kerja Waktu Tertentu (PKWT). Pengaturan mengenai PKWT bahkan telah dibuat sedemikian rupa untuk tetap dapat melindungi pekerja meskipun hubungan kerjanya bersifat kontrak. Sebagai contoh, pemberi kerja wajib untuk tetap mengikutkan pekerja dengan PKWT dalam program BPJS Ketenagakerjaan untuk melindungi haknya mendapatkan jaminan sosial, sebagaimana diatur dalam Keputusan Menteri Tenaga Kerja No. KEP150/MEN/1999 tentang Penyelenggaraan Program Jaminan Sosial Tenaga Kerja bagi Tenaga Kerja Harian Lepas, Borongan, dan PKWT.

Selain itu, PKWT dibatasi penggunaannya hanya bagi jenis-jenis pekerjaan tertentu, antara lain: pekerjaan yang selesai sekali atau bersifat sementara; pekerjaan musiman; pekerjaan yang terkait dengan produk baru, kegiatan baru, atau produk tambahan yang masih dalam percobaan atau penjajakan; dan/atau pekerjaan yang dapat selesai dalam jangka waktu maksimal 3 tahun. Artinya, tidak semua jenis pekerjaan memungkinkan untuk diselenggarakan dengan menggunakan PKWT. PKWT juga dibatasi dengan waktu yang rigid, yakni maksimal 2 tahun dengan masa perpanjangan 1 tahun, atau 2 tahun dengan pembaharuan perjanjian maksimal 2 tahun.

Ketentuan lebih lanjut terkait PKWT diatur dalam Keputusan Menteri Tenaga Kerja dan Transmigrasi Republik Indonesia Nomor KEP.100/MEN/VI/2004 tentang 
Ketentuan Pelaksanaan Perjanjian Kerja Waktu Tertentu. Keputusan ini mengatur ketentuan-ketentuan khusus bagi PKWT, seperti perjanjiannya yang wajib dibuat secara tertulis, dan kontrak tersebut wajib untuk didaftarkan ke Dinas Ketenagakerjaan setempat. Meski ketentuan terkait PKWT tidak memuat sanksi jika dilanggar, namun UndangUndang Ketenagakerjaan maupun Kepmenaker tentang PKWT mengatur bahwa apabila terdapat ketentuan yang tidak dipenuhi, sebagai contoh, misalnya perjanjian tidak dibuat secara tertulis, maka secara hukum PKWT akan berubah menjadi PKWTT (Perjanjian Kerja Waktu Tidak Tertentu) atau perjanjian kerja tetap.

Dari ketentuan-ketentuan di atas, secara yuridis terlihat bahwa hubungan kerja non-standar dengan jenis temporary work telah diregulasi dengan cukup baik di Indonesia. Kecuali terkait dengan hak-hak yang didapatkan saat terjadi pemutusan hubungan kerja, seperti pesangon dan uang penghargaan masa kerja, secara umum hukum ketenagakerjaan Indonesia memberikan hak yang sama bagi pekerja kontrak maupun pekerja tetap.

Meski begitu, penerapan ketentuanketentuan terkait PKWT masih perlu banyak dikritisi. Sebagai contoh, meski secara yuridis telah ada pembatasan jenis pekerjaan yang boleh dikerjakan dengan menggunakan perjanjian kerja kontrak, data pada tahun 2016 menunjukkan bahwa 1 dari 4 pekerja di Indonesia bekerja dalam hubungan kerja kontrak.(Landau, Mahy, \& Mitchell, 2015) Menurut data dari KSBI di 2010, $65 \%$ dari total 33 juta pekerja di sektor formal merupakan pekerja kontrak (di dalamnya termasuk pekerja outsourcing), peningkatan yang cukup drastis dari angka $30 \%$ di tahun 2005.(Tjandraningsih, 2013) Sayangnya, saat ini belum tersedia referensi data lebih baru yang dapat digunakan untuk menganalisis lebih lanjut angka-angka tersebut.

Yang menarik, Keputusan Menteri Tenaga Kerja dan Transmigrasi Republik Indonesia Nomor KEP.100/MEN/VI/2004 tenang Ketentuan Pelaksanaan Perjanjian Kerja Waktu Tertentu juga mengatur jenis hubungan kerja non-standar lain yakni melalui perjanjian kerja harian lepas. Perjanjian kerja harian lepas dimaksudkan untuk pekerjaan-pekerjaan tertentu yang berubah-ubah dalam hal waktu dan volume pekerjaan serta upah didasarkan pada kehadiran. Perjanjian kerja harian lepas dilakukan dengan ketentuan pekerja bekerja kurang dari 21 hari dalam 1 bulan.

Jika dikaitkan dengan pembagian jenis non-standard employment relationship oleh ILO, maka pekerja harian lepas ini dapat dipadankan dengan casual work ataupun on-call work. Ketentuan terkait dengan pekerja harian lepas ini secara umum hampir sama dengan ketentuan PKWT, kecuali satu hal, yakni jangka waktunya dikecualikan dari ketentuan jangka waktu PKWT pada umumnya. Celah ini yang penulis rasa merugikan posisi dari pekerja harian lepas, karena secara hukum mereka dimungkinkan untuk terus menerus dipekerjakan dalam hubungan kerja yang tidak standar, dengan hak-hak yang seringkali diskriminatif dibanding pekerja tetap.

\section{b. Hubungan kerja multi-pihak (multi-party employment relationship)}

Jenis hubungan kerja non-standar yang kedua adalah multi-party employment relationship. Secara harfiah, ini adalah jenis pekerjaan yang melibatkan lebih dari dua pihak dalam hubungan kerjanya. Hubungan kerja dengan jenis ini juga bukanlah hal yang asing dalam konteks hukum ketenagakerjaan di Indonesia. Sebagaimana diketahui bahwa Undang- 
Undang Ketenagakerjaan telah mengenal konsep outsourcing berupa perjanjian alih daya maupun perjanjian pemborongan. Dalam hubungan outsourcing, terdapat 3 pihak yang terlibat, yakni pekerja, pengusaha, dan perusahaan alih daya. Pekerja tidak memiliki hubungan kerja langsung dengan pengusaha tempat dia bekerja, melainkan dengan perusahaan alih daya/outsourcing. Hubungan kerja jenis ini mengakibatkan hubungan yang bersifat segitiga atau triangular relationship, yang menyebabkan hubungan kerjanya menjadi tidak standar.

Outsourcing merupakan jenis hubungan kerja yang mulai dikenal di Indonesia sejak tahun 1990-an. Penggunaan hubungan kerja tiga pihak ini terus meningkat dari tahun ke tahun, terutama setelah diakui secara resmi dalam Undang-Undang Ketenagakerjaan.(Izzati, 2018) UndangUndang Nomor 13 Tahun 2003 tidak secara eksplisit menyebut kata outsourcing, namun Pasal 64 UndangUndang ini menyebut bahwa "perusahaan dapat menyerahkan sebagian pelaksanaan pekerjaan kepada perusahaan lainnya melalui perjanjian pemborongan pekerjaan atau penyediaan jasa pekerja/buruh yang dibuat secara tertulis." Perjanjian pemborongan pekerjaan dan penyediaan jasa pekerja/buruh inilah yang dikenal luas sebagai outsourcing yang berlaku saat ini.

Pasal $65 \quad$ Undang-Undang Ketenagakerjaan memberi ketentuan bahwa pekerjaan yang dapat diserahkan kepada perusahaan lain harus memenuhi syarat-syarat, antara lain: a) dilakukan secara terpisah dari kegiatan utama; b) dilakukan dengan perintah langsung atau tidak langsung dari pemberi pekerjaan; c) merupakan kegiatan penunjang perusahaan secara keseluruhan; dan d) tidak menghambat proses produksi secara langsung.
Sedangkan Pasal 66 mengatur bahwa pekerja/buruh dari perusahaan penyedia jasa pekerja/buruh tidak boleh digunakan oleh pemberi kerja untuk melaksanakan kegiatan pokok atau kegiatan yang berhubungan langsung dengan proses produksi, kecuali untuk kegiatan jasa penunjang atau kegiatan yang tidak berhubungan langsung dengan proses produksi.

Terkait dengan perlindungan pekerja dalam hubungan outsourcing, Pasal 65 ayat (4) Undang-Undang Ketenagakerjaan menjamin bahwa perlindungan kerja dan syarat-syarat kerja bagi pekerja/buruh pada perusahaan lain sekurang-kurangnya sama dengan perlindungan kerja dan syarat kerja pada perusahaan pemberi pekerjaan atau sesuai dengan peraturan perundang-undangan yang berlaku. Lalu di Pasal 66 ayat (2) disebutkan bahwa penyedia jasa pekerja/buruh untuk kegiatan jasa penunjang atau kegiatan yang tidak berhubungan langsung dengan produksi harus memenuhi syarat, antara lain: adanya hubungan kerja yang dibuat berdasarkan perjanjian kerja tertulis, serta menyebutkan bahwa perlindungan upah dan kesejahteraan, syarat kerja, serta perselisihan yang timbul menjadi tanggung jawab perusahaan penyedia jasa pekerja/buruh.

Setahun kemudian, ketentuan terkait outsourcing diatur secara lebih rigid dalam Keputusan Menteri Tenaga Kerja dan Transmigrasi Nomor KEP.101/MEN/VI/2004 tentang Tata Cara Perijinan Penyediaan Jasa Pekerja/Buruh dan Keputusan Menteri Tenaga Kerja dan Transmigrasi Nomor KEP.220/MEN/X/2004 tentang Syaratsyarat Penyerahan Sebagian Pelaksanaan Pekerjaan Kepada Perusahaan Lain. Pada tahun 2012, aturan ini dicabut dan diganti menjadi Peraturan Menteri Tenaga Kerja dan Transmigrasi Republik Indonesia Nomor 19 Tahun 2012 tentang Syarat- 
Syarat Penyerahan Sebagian Pelaksanaan Pekerjaan kepada Perusahaan Lain (Permenaker 19/2012). Alasan utama munculnya Permenaker 19/2012 adalah karena adanya Putusan Mahkamah Konstitusi No 27/PUUIX/2011 yang menyatakan bahwa isi Pasal 65 ayat (7) dan Pasal 66 ayat (2) huruf (b) Undang-Undang Ketenagakerjaan inkonstitusional bersyarat unconstitutional).

Perubahan yang menonjol pada Permenaker 19/2012 adalah munculnya pembatasan jenis pekerjaan yang dapat diserahkan kepada perusahaan penyedia jasa. Pasal 17 ayat (2) menyebut bahwa pekerjaan yang dapat diserahkan kepada perusahaan penyedia jasa pekerja/buruh harus merupakan kegiatan jasa penunjang atau yang tidak berhubungan langsung dengan proses produksi. Lalu Pasal 17 ayat (3) mengatakan bahwa kegiatan jasa penunjang tersebut meliputi: a) usaha pelayanan kebersihan (cleaning service); b) usaha penyediaan makanan bagi pekerja/buruh (catering); c) usaha tenaga pengaman (security/satuan pengamanan); d) usaha jasa penunjang di pertambangan dan perminyakan; dan e. usaha penyediaan angkutan bagi pekerja/buruh.

Perlindungan terhadap pekerja dalam sistem outsourcing juga lebih dijamin dalam Permenaker ini, sebagai contoh, Pasal 29 ayat (2) menyebutkan bahwa dalam hal hubungan kerja pekerja outsourcing adalah PKWT, maka perjanjian kerja harus memuat: a) jaminan kelangsungan bekerja; b) jaminan terpenuhinya hak-hak pekerja/buruh sesuai dengan peraturan perundang-undangan dan yang diperjanjikan; dan c) jaminan perhitungan masa kerja apabila terjadi pergantian perusahaan penyedia jasa pekerja/buruh untuk menetapkan upah.

Permenaker 19/2012 hingga saat ini telah mengalami dua kali perubahan, yakni melalui Peraturan Menteri
Ketenagakerjaan Nomor 27 Tahun 2014 (Permenaker 27/2014) dan Peraturan Menteri Ketenagakerjaan Nomor 11 Tahun 2019 (Permenaker 11/2019). Perubahan kedua melalui Permenaker $11 / 2019$ secara umum menegaskan kembali perlidungan bagi pekerja dalam sistem outsourcing, contohnya ketentuan Pasal 19 yang ditambah satu poin di huruf $d$ yang menyebutkan bahwa perjanjian penyediaan jasa pekerja wajib memuat pasal mengenai kewajiban memenuhi hak pekerja/buruh sesuai dengan ketentuan peraturan perundang-undangan.

Meskipun telah diatur secara cukup rigid dan berupaya menjamin pemenuhan hak dari pekerja di sistem outsourcing, kenyataan di lapangan berkata lain. Secara empiris, hingga saat ini hubungan kerja outsourcing di Indonesia masih banyak menimbulkan polemik. Pekerja maupun serikat pekerja banyak menolak penyelenggaraan sistem outsourcing karena dirasa sangat merugikan pihak pekerja.(Izzati, 2018; Nafila, Kristine, \& Wijaya, 2017; Saefuloh, 2011; Triyono, 2011)

Belum ada data resmi presentase pekerja outsourcing di Indonesia, namun beberapa serikat pekerja mengindikasikan bahwa presentase penggunaan outsourcing sangatlah tinggi, utamanya di beberapa jenis industri. Angka yang disebut oleh serikat pekerja bahkan mencapai sekitar $40 \%$ di industri metal, dan $60 \%$ di industri garmen.(Landau et al., 2015) Studi tentang praktik outsourcing tenaga kerja di sektor manufuktur menemukan bahwa banyak pekerja yang bahkan dialihkan dari kontrak kerja permanen menjadi pekerja kontrak melalui sistem outsourcing. Praktik ini lazim dilakukan untuk mengurangi tanggung jawab pengusaha terhadap pekerja.(Tjandraningsih, 2013) 


\section{c. Pekerjaan paruh waktu (part- time work) dan pekerjaan panggilan (on-call work)}

Jenis hubungan kerja non-standar yang ketiga adalah part-time work dan on-call work. Era revolusi indostri keempat menyebabkan semakin banyak orang yang bekerja dengan jenis hubungan kerja part-time maupun oncall, terutama bagi kalangan pekerja muda. Hal ini dikarenakan, jenis-jenis pekerjaan yang muncul dalam era revolusi industri 4.0 merupakan pekerjaan yang bisa dikerjakan secara remote, sehingga akan makin banyak orang yang bekerja tidak secara fulltime sebagaimana pekerjaan tradisional pada umumnya.(De Stefano, 2015) Secara kuantitatif, pekerja paruh waktu diartikan sebagai pekerja yang bekerja kurang dari 35 jam seminggu, hal ini mengacu pada Peraturan Menteri Tenaga Kerja Nomor 1 Tahun 2014 yang mengatur standar kerja normal adalah sebanyak 35 jam seminggu. Sedangkan on-call work berarti seseorang hanya bekerja saat dibutuhkan dan tidak terikat pada waktu tertentu.

Dari sisi pengaturan hukum, hingga saat ini jenis hubungan kerja paruh waktu maupun on-call work belum memiliki payung hukum yang memadai. Sebagai gambaran, Undang-Undang Nomor 13 Tahun 2003 tentang Ketenagakerjaan masih mengatur jam kerja secara rigid, dengan memberikan pengecualian-pengecualian yang terbatas.

Karena belum adanya aturan hukum bagi hubungan kerja non-standar dengan kategori part-time work maupun on-call work, maka perlindungan hukum bagi pekerja-pekerja part-time maupun on-call ini sampai saat ini dapat dikatakan belum ada. Akibatnya, hal-hal terkait hak dasar pekerja, seperti upah minimum, jam kerja, ataupun hak-hak jaminan sosial bagi pekerja part-time maupun on-call work belum dapat terlindungi.

Padahal secara empiris, jenis hubungan kerja yang bersifat part-time ataupun on-call work sangat mudah ditemui di sekitar kita. Meskipun tidak ada data resmi yang mencatat berapa jumlah pekerja paruh waktu di Indonesia, riset ILO menunjukkan bahwa terjadi kenaikan tren pekerja paruh waktu di Indonesia, dari sekitar $16,1 \%$ di tahun 2006 , menjadi $22,7 \%$ di tahun 2014.(Nguyen et al., n.d.) Demografi utama dari pekerja paruh waktu adalah perempuan, karena jenis hubungan kerja paruh waktu memungkinkan wanita yang masih memiliki tanggung jawab mengurus keluarga di rumah untuk tetap bekerja. Selain itu, demografi pekerja paruh waktu juga banyak diisi oleh pekerja muda, salah satunya adalah mahasiswa yang hanya bisa bekerja paruh waktu karena masih memiliki kesibukan berkuliah. (Midayati, 2018)

Hadirnya jenis hubungan kerja paruh waktu merupakan salah satu perwujudan dari fleksibilitas tenaga kerja. Dengan waktu kerja yang lebih singkat, atau diatur dalam sistem kerja fleksibel (seperti yang dikategorikan dalam on-call work) maka dapat memberikan keuntungan bagi sisi perusahaan.(Triani \& Ariana, 2014) Di sisi lain, sistem kerja paruh waktu juga memberikan keuntungan bagi pekerja karena memberikan kesempatan bagi pekerja yang tidak dapat bekerja penuh waktu, untuk tetap bisa mendapat pengalaman kerja dan tambahan finansial. Namun, ketiadaan aturan hukum yang melindungi pekerja paruh waktu, sangat mungkin mendudukkan mereka pada posisi rentan mengalami marginalisasi dari sisi ketersediaan perlindungan sosial, kedudukan dalam kerja, serta upah yang lebih sedikit dibanding dengan pekerja lain di perusahaan yang sama.(Nguyen et al., n.d.) 
Penelitian yang dilakukan oleh Rabbani di tahun 2017 tentang kerja layak bagi mahasiswa pekerja kontrak paruh waktu, misalnya, menemukan bahwa pekerja paruh waktu di PT. Aseli Dagadu Djokja tidak mendapat upah sesuai dengan UMK Kabupaten Bantul yang berlaku. Upah pekerja part time di sana berada pada kisaran 42,4\%-58,9\% dari UMK yang berlaku.(Rabbani, 2019) Pembayaran upah yang tidak sesuai dengan standar upah minimum ini dimungkinkan terjadi karena ketiadaan pengaturan mengenai upah bagi pekerja paruh waktu.

Selanjutnya terkait dengan on-call work, Tjandraningsih di tahun 2013 menyebut dalam tulisannya bahwa arus informalisasi di Indonesia telah menghasilkan banyak pekerjaan tidak tetap di sektor formal melalui kontrak jangka pendek, outsourcing, magang, kerja paruh waktu, upah boronga, dan on call work atau pekerjaan berdasarkan panggilan.(Tjandraningsih,

Namun, hingga tulisan ini dibuat, penulis belum menemukan penelitian empiris yang secara spesifik membahas mengenai on-call work di Indonesia.

\section{d. Hubungan kerja terselubung (disguise employment relationship) dan hubungan kerja mandiri yang bergantung (dependent self-employment)}

Kategori hubungan kerja nonstandar keempat adalah disguise employment relationship dan dependent self-employment. Disguise employment relationship atau 'hubungan kerja terselubung', didefinisikan oleh ILO sebagai situasi yang terjadi ketika seorang majikan memperlakukan seorang individu bukan sebagai pekerja, dengan cara menyembunyikan status hukumnya sebagai pekerja.(Champeau et al., 2016) Sedangkan dependent-self employment atau 'hubungan kerja mandiri yang bergantung' merupakan situasi yang terjadi kala pekerja melakukan layanan di bawah kontrak yang bukan kontrak kerja, tidak dikategorikan sebagai pekerja, namun mereka sebenarnya bergantu pada perusahaan atau majikan tertentu terhadap pendapatan mereka, serta cara kerja mereka pun masih dikontrol oleh perusahaan/majikan tersebut.

Disguise employment relationship dan dependent self-employment merupakan jenis non-standard employment lazim ditemui, utamanya dalam era gig economy. Gig economy sendiri dapat didefinisikan sebagai 'designated work that is mediated through online web platform' atau bisa juga disebut sebagai 'a labour market characterized by the prevalence of short-term contracts or freelance work, as opposed to permanent jobs.' (De Stefano, 2015; Joe, 2017; Stewart \& Stanford, 2017) Secara umum, gig economy adalah situasi dimana orangorang tidak mau pergi bekerja atau pun tidak mau mempunyai pekerja, namun mereka akan menyelesaikan tugastugas, berkoordinasi melalui media tatap muka online dan kompensasinya ditransfer secara digital. Kondisi pasar yang besar memungkinkan kemudahan penjual dan pembeli untuk terhubung. Pertumbuhan gig economy dicirikan dengan platform online dan pekerja mandiri yang terisolasi.

Di Indonesia, contoh paling umum dari gig economy dapat dilihat dari dua perusahaan gig economy raksasa: GoJek dan Grab. Kedua perusahaan ini, melalui hubungan yang dia ciptakan dengan para pengemudinya, memunculkan jenis hubungan hukum yang tidak dapat dikategorikan sebagai hubungan kerja, karena tidak memenuhi unsur-unsur hubungan kerja sebagaimana tercantum dalam UndangUndang Ketenagakerjaan, yakni: pekerjaan, upah, dan perintah. Pengusaha, dalam hal ini platform penyedia jasa, berdalih bahwa mereka hanya bertidak sebagai perantara antara 
pekerja dengan klien atau konsumen, sehingga mereka tidak memberikan perintah dan upah secara langsung. Karena itulah, perjanjian yang muncul diantara keduanya adalah perjanjian kemitraan, bukan perjanjian kerja.

Meski begitu, hubungan ini secara empiris tidak dapat sepenuhnya dikategorikan sebagai hubungan kemitraan karena pekerja yang sangat terikat terhadap platform. Sebagai contoh, pelayanan yang diberikan oleh pekerja dipantau secara terus menerus oleh perusahaan penyedia jasa melalui mekanisme rating, yang mana ketika pekerjaan mendapatkan rating rendah maka perusahaan penyedia layanan dapat mengakhiri 'hubungan kemitraan' secara sepihak. Pekerja juga diikat dengan ketentuan-ketentuan yang diatur oleh perusahaan penyedia jasa, sehingga tidak tepat jika pekerja dikatakan sebagai 'pekerja mandiri'. Karena itulah, jenis hubungan yang muncul dalam gig economy ini dapat dikategorikan sebagai dependent selfemployment. Implikasi dari jenis hubungan yang tidak dapat dikategorikan sebagai hubungan kerja ini jelas, yakni tidak adanya perlindungan yang diberikan terhadap pekerja yang terlibat di dalamnya.

Selama beberapa tahun terakhir, muncul berbagai kritik terhadap kondisi kerja para pengemudi transportasi online ini, antara lain: penurunan kualitas pekerjaan, eksploitasi bentuk baru di era digital, lemahnya perlindungan terhadap pekerja, hingga kemungkinan 'race to the bottom' dimana pekerja mendapatkan gaji yang minimum. (Nastiti, 2017) Status mitra memang seakan memberikan fleksibilitas pada pekerja untuk menentukan jam kerja dan bebas mematikan serta menghidupkan aplikasinya, sehingga pengemudi merasa memiliki kontrol atas apa yang mereka kerjakan.(Berger, Frey, Levin, \& Danda, 2019; Manyika et al., 2016)
Tapi di sisi lain, pengemudi Go-Jek dan Grab tidak memiliki hak dasar seperti yang diperoleh pekerja yang berlabel karyawan, misalnya asuransi, jaminan sosial, dan cuti berbayar.

Cherry (2017) menyatakan bahwa status pekerja menjadi indikator yang penting guna melindungi hak-hak pekerja. Namun demikian, hubungan yang terjadi di Go-jek dan Grab berhasil menciptakan ilusi seolah perusahaan dan pekerja memiliki posisi yang setara dengan statusnya sebagai 'mitra/partner'.(Cherry \& Aloisi, 2016) Padahal, kenyataannya posisi antara pengusaha dan mitra dalam hubungan tersebut sama sekali tidak setara. Hal ini terbukti, misalnya, dengan tidak pernahnya pekerja dilibatkan dalam proses pengambilan keputusan yang mempengaruhi pekerja (contoh: perubahan sistem poin yang berimplikasi pada besaran pendapatan para pengemudi).

Penelitian yang dilakukan oleh Dian Fatmawati dan Falikul Isbah menemukan bahwa pekerjaan sebagai pengemudi transportasi online merupakan jenis pekerjaan baru yang banyak diminati oleh kaum muda. Pekerjaan jenis ini menjadi kesempatan bagi para pekerja muda yang kesulitan mendapatkan akses atau berkompetisi pada jenis-jenis pekerjaan lain. (Fatmawati, Isbah, \& Kusumaningtyas, 2019) Namun, temuan riset tersebut juga menemukan bahwa pekerjaan ini membuat para pekerja muda kesulitan untuk perpindah ke pekerjaan baru yang lebih baik, karena tidak banyak keterampilan baru yan didapatkan selama melakukan pekerjaan. Akibatnya, pekerja muda tersebut justru terjebak ke posisi yang secata teoritik dapat dinamai dengan proses deskilling dan skill trap. 


\section{Implikasi Pengaturan Hukum dalam Tiap-Tiap Jenis Hubungan Kerja Non-Standar terhadap Hak-Hak Dasar Pekerja}

Secara umum, pekerja yang berada dalam hubungan kerja non-standar memiliki posisi yang lebih rentan dibandingkan dengan pekerja yang berada dalam hubungan kerja standar. Sebagai contoh, penelitian yang dilakukan oleh Federasi Serikat Pekerja Metal Indonesia (FSPMI) dan Friedrich Ebert Stiftung (FES) menemukan bahwa terdapat perbedaan upah yang cukup signifikan antara pekerja yang bekerja sebagai pekerja tetap, pekerja kontrak dengan PKWT, dan pekerja outsourcing.(Indrasari Tjandranigsih, Herawati, \& Suhadmadi, 2010)

Selain itu, penelitian yang dilakukan oleh Inggrid Landau, Petra Mahy, dan Richard Mitchell terhadap hubungan kerja non-standard di India, Indonesia, dan Vietnam pada tahun 2015 menyimpulkan bahwa pekerja dalam hubungan kerja nonstandar hampir tidak memiliki employment security, dalam artian keamanan keberlangsungan kerja. Karena pekerja dalam hubungan kerja non-standar biasanya memang terikat dalam kontrak perjanjian kerja waktu tertentu, yang tidak menjamin keberlangsungan kerja setelah kontrak tersebut habis.(Landau et al., 2015) Pekerja dalam hubungan kerja non-standard juga sangat jarang memperoleh jaminan sosial ketenagakerjaan, jika dibandingkan dengan pekerja dalam hubungan kerja standar.

Bukti-bukti empiris menunjukkan bahwa pekerja dalam hubungan kerja nonstandar juga lebih sering mengalami pelanggaran hak-hak ketenagakerjaan. Tjandraningsih, contohnya, menemukan bahwa pekerja outsourcing lebih sering mengalami diskriminasi dengan basis usia, gender, atau hubungan perkawinan.(Indrasari Tjandranigsih et al.,
2010) Selain itu, pekerja dalam hubungan kerja non-standar juga lebih jarang terlibat dalam serikat pekerja karena adanya ketakukan kehilangan pekerjaan.(Landau et al., 2015)

Dalam praktik Hukum Ketenagakerjaan di Indonesia, sudah jamak diakui bahwa aturan hukum tidak bisa dijadikan satusatunya faktor yang berpengaruh pada situasi dan kelayakan kerja. Banyak faktor lain yang juga mempengaruhi, seperti bagaimana pelaksanaan aturan hukum tersebut, keaktifan serikat pekerja dan dewan pengawas, hingga kondisi sosial di daerah tempat bekerja. Meski begitu, ada atau tidaknya pengaturan hukum dalam suatu hubungan kerja tetap saja memiliki pengaruh terhadap hak-hak dasar yang diterima oleh pekerja dalam hubungan kerja tersebut. Pada konteks hubungan kerja nonstandar, penulis mencoba merangkum kaitan antara adanya peraturan perundangundangan dalam tiap jenis hubungan kerja non-standar dengan hak-hak yang secara yuridis wajib didapatkan oleh pekerja, dapat dilihat dalam tabel 1 .

Dari tabel 1, dapat disimpulkan bahwa terlepas dari implementasinya di lapangan, hubungan kerja non-standar yang telah diatur dalam hukum ketenagakerjaan Indonesia, seperti pekerja dalam PKWT dan pekerja outsourcing, memiliki jaminan hakhak dasar pekerja yang lebih baik, jika dibandingkan dengan pekerja part-time, pekerja on-call, ataupun pekerja gig economy yang sama sekali tidak memiliki payung hukum di Indonesia. Dengan makin menjamurnya pekerja yang bekerja dalam hubungan kerja non-standar, pemerintah perlu lebih serius memikirkan perlindungan hukum bagi pekerja-pekerja tersebut, karena ketiadaan peraturan hukum terhadap mereka berimplikasi langsung terhadap hak-hak dasar yang mereka dapatkan. 
Tabel 1.

Hak Pekerja pada masing-masing Jenis Hubungan Kerja Non-Standar dalam Hukum Ketenagakerjaan Indonesia dibandingkan dengan Hak Pekerja dalam Hubungan Kerja Standar

\begin{tabular}{|c|c|c|c|c|c|}
\hline Hak Pekerja & $\begin{array}{c}\text { Pekerja dalam } \\
\text { Hubungan } \\
\text { Standar }\end{array}$ & $\begin{array}{l}\text { Pekerja } \\
\text { Kontrak } \\
(\text { PKWT) }\end{array}$ & $\begin{array}{c}\text { Pekerja } \\
\text { Outsourcing }\end{array}$ & $\begin{array}{c}\text { Pekerja } \\
\text { Part Time / } \\
\text { On Call } \\
\end{array}$ & $\begin{array}{c}\text { Pekerja } \\
\text { Gig } \\
\text { Economy }\end{array}$ \\
\hline Hak Berserikat & $\mathrm{V}$ & $\mathrm{V}$ & $\begin{array}{l}\text { Hanya pada } \\
\text { pemberi kerja } \\
\text { langsung }\end{array}$ & $\mathrm{x}$ & $\mathrm{x}$ \\
\hline $\begin{array}{l}\text { Perlakuan non- } \\
\text { diskriminasi }\end{array}$ & $\mathrm{v}$ & $\mathrm{V}$ & $\mathrm{V}$ & $\mathrm{x}$ & $\mathrm{x}$ \\
\hline Perlindungan K3 & $\mathrm{V}$ & $\mathrm{v}$ & $\mathrm{V}$ & $\mathrm{x}$ & $\mathrm{x}$ \\
\hline Jaminan Sosial & $\mathrm{v}$ & $\mathrm{v}$ & $\begin{array}{c}\text { Hanya jaminan } \\
\text { kecelakaan kerja \& } \\
\text { jaminan kematian }\end{array}$ & $\mathrm{x}$ & $\mathrm{x}$ \\
\hline Upah Minimum & $\mathrm{V}$ & $\mathrm{V}$ & $\mathrm{V}$ & $\mathrm{x}$ & $\mathrm{x}$ \\
\hline Jam Kerja & $\mathrm{v}$ & $\mathrm{v}$ & $\mathrm{v}$ & $\mathrm{x}$ & $\mathrm{x}$ \\
\hline THR & $\mathrm{v}$ & $\mathrm{v}$ & $\mathrm{v}$ & $\mathrm{x}$ & $\mathrm{x}$ \\
\hline
\end{tabular}

Sumber: Landau et al., 2015, dan hasil observasi yang diolah oleh penulis.

\section{Hubungan Kerja Non-Standar dalam Undang-Undang Cipta Kerja}

Disahkannya Undang-Undang Nomor 11 Tahun 2020 tentang Cipta Kerja (untuk selanjutnya disebut "UU Cipta Kerja") pada tanggal 5 Oktober 2020 menimbulkan perubahan yang cukup signifikan terhadap pengaturan hubungan kerja di Indonesia. UU Cipta Kerja, khususnya dalam Bab Ketenegakerjaan mengubah beberapa undang-undang terkait dengan ketenagakerjaan, salah satunya adalah Undang-Undang Nomor 13 Tahun 2003.

Sayangnya, UU Cipta Kerja tidak memberikan tambahan perlindungan hukum bagi pekerja dalam hubungan kerja nonstandar. Alih-alih, ketentuan baru ini justru mengurangi perlindungan hukum bagi pekerja dalam dua jenis hubungan kerja nonstandar, yakni pekerja kontrak (PKWT) dan outsourcing.

Dalam kaitannya dengan pekerja kontrak, salah satu yang paling berpengaruh dalam UU Cipta Kerja adalah dihapusnya ketentuan batas waktu PKWT yang sebelumnya diatur dalam Pasal 59 UndangUndang Ketenagakerjaan. Padahal, pembatasan ini penting untuk mencegah penyalahgunaan penggunaan PKWT yang merugikan pekerjaan.

Terkait dengan outsourcing, hal paling berpengaruh adalah dihilangkannya pembatasan jenis-jenis pekerjaan yang dapat di-outsourcing dalam UU Cipta Kerja. Sebelumnya, Pasal 66 ayat (1) UU Ketenagakerjaan menyebutkan bahwa: "Pekerja/buruh dari perusahaan penyedia jasa pekerja/buruh tidak boleh digunakan oleh pemberi kerja untuk melaksanakan kegiatan pokok atau kegiatan yang berhubungan langsung dengan proses produksi, kecuali untuk kegiatan jasa penunjang atau kegiatan yang tidak berhubungan langsung dengan proses produksi."

Sebagaimana telah dijelaskan di atas, hal ini menunjukkan bahwa UU Ketenagakerjaan memberikan pembatasan secara eksplisit bahwa outsourcing tidak boleh dilakukan bagi pekerjaan-pekerjaan yang bersifat sentral dalam perusahaan. Pembatasan ini justru dihapuskan perubahan Pasal 66 UU Cipta Kerja. Implikasinya, hubungan outsourcing diprediksi akan semakin menjamur karena dapat digunakan untuk jenis pekerjaan apapun. 


\section{Simpulan dan Saran}

Berdasarkan penelusuran normatif yang dilakukan oleh penulis, dapat disimpulkan bahwa secara yuridis, terdapat dua bentuk hubungan kerja non-standar yang dikenal dalam hukum ketenagakerjaan Indonesia, yakni hubungan kerja dengan sistem kontrak (PKWT) dan hubungan kerja outsourcing. Dua jenis hubungan kerja ini, meskipun sifatnya non-standar, telah diatur dengan cukup jelas dalam Undang-Undang Nomor 13 Tahun 2003 tentang Ketenagakerjaan maupun aturan turunannya.

Sedangkan, dua bentuk hubungan kerja non-standar lain, yakni hubungan kerja parttime atau on-call dan disguised employment relationship belum ditemukan pengaturannya dalam hukum ketenagakerjaan Indonesia. Padahal, jika dikaji secara empiris, data menunjukkan bahwa baik pekerja part-time maupun pekerja gig-economy yang dapat dikategorikan sebagai disguised employment relationship terus meningkat jumlahnya di Indonesia. Implikasinya, pekerja yang berada dalam hubungan kerja part-time maupun gig-economy tidak mendapatkan jaminan hak-hak dasar pekerja, seperti upah minimum, jaminan sosial, maupun kesehatan dan keselamatan kerja.

Meskipun adanya pengaturan hukum tidak bisa dijadikan satu-satunya faktor yang berpengaruh pada situasi dan kelayakan kerja, namun, pengaturan hubungan kerja non-standar dalam hukum nasional merupakan langkah awal untuk mewujudkan kerja layak bagi pekerja dalam hubungan kerja non-standar. Seiring dengan meningkatnya jumlah pekerja dalam hubungan kerja non-standar akibat revolusi industri 4.0, pemerintah perlu segera berbenah menyiapkan perlindungan hukum yang sesuai.

Sayangnya, bahkan dalam UU Cipta Kerja yang baru saja disahkan oleh pemerintah, tidak terlihat ada upaya pemberian perlindungan hukum tambahan bagi pekerja dalam hubungan kerja nonstandar. Yang terlihat justru adanya pengurangan perlindungan hukum bagi pekerja dalam dua jenis hubungan kerja nonstandar, yakni hubungan kerja kontrak dan outsourcing. Padahal, tanpa adanya payung hukum yang jelas, bukan tidak mungkin ekploitasi ketenagakerjaan terhadap pekerja dengan hubungan kerja non-standar akan benar-benar terjadi.

\section{DAFTAR PUSTAKA}

Berger, T., Frey, C. B., Levin, G., \& Danda, S. R. (2019). Uber Happy? Work and Well-being in the "Gig Economy." Economic Policy. https://doi.org/10.1093/epolic/eiz007

Champeau, M., Arsac, M., Pineau, P., \& Denyset, F. (2016). Non-Standard Employment Around the World: Understanding challenges, shaping prospects. In ILO Cataloguing in Publication Data. https://doi.org/https://www.ilo.org/wcm sp5/groups/public/---dgreports/--dcomm/--publ/documents/publication/wcms_534 326.pdf

Cherry, M. A., \& Aloisi, A. (2016). "Dependent Contractors" in the Gig Economy: A Comparative Approach. SSRN Electronic Journal. https://doi.org/10.2139/ssrn.2847869

Darma, S. A. (2017). Kedudukan Hubungan Kerja; Berdasarkan Sudut Pandang Ilmu Kaidah Hukum Ketenagakerjaan dan Sifat Hukum Publik dan Privat. Mimbar Hukum.

https://doi.org/10.22146/jmh.25047

De Stefano, V. (2015). The Rise of the "Just-in-Time Workforce": On-Demand Work, Crowd Work and Labour Protection in the "Gig-Economy." SSRN Electronic Journal. https://doi.org/10.2139/ssrn.2682602

Fatmawati, D., Isbah, F., \& Kusumaningtyas, A. P. (2019). Pekerja Muda dan Ancaman Deskilling-Skill Trap di Sektor Transportasi Berbasis 
Daring. Jurnal Studi Pemuda, 8(1), 29. https://doi.org/10.22146/studipemudaug m.45301

Hernawan, A. (2014). Industrial Relations in The Perspective of Justice Theory by John Rawls. Mimbar Hukum - Fakultas Hukum Universitas Gadjah Mada. https://doi.org/10.22146/jmh.16042

Indrasari Tjandranigsih, Herawati, R., \& Suhadmadi. (2010). Praktek Kerja Kontrak dan Outsourcing Buruh di Sektor Industri Metal di Indonesia. Akatiga, 1-6.

International Labour Organization. (2015). Non-standard forms of employment. International Labour Organization. https://doi.org/10.1164/rccm.2012091671OC

Izzati, N. R. (2018). Improving Outsourcing System in Indonesia: Fixing The Gap of Labour Regulation. Mimbar Hukum Fakultas Hukum Universitas Gadjah Mada.

https://doi.org/10.22146/jmh.28372

Joe, G. M. S. (2017). Towards a Fairer GigEconomy. In Towards a fairer gig economy.

Landau, I., Mahy, P., \& Mitchell, R. (2015). The regulation of non-standard forms of employment in India, Indonesia and Viet Nam. (63). Retrieved from http://eprints.soas.ac.uk/20898/1/wcms 414583.pdf

Majanto, L. F. (2002). Studi Profil Pekerja di Sektor Informal dan Arah Kebijakan ke Depan. In Direktorat Ketenagakerjaan dan Analisis Ekonomi.

Manyika, J., Lund, S., Kelsey, R., Mischke, J., Deepa, M., \& Bughin, J. (2016). Independent Work: Choice, Necessity, and the Gig Economy. In McKinsey Global Institute. https://doi.org/10.1093/jicru/nd1025

Market, L., \& Group, P. (2002). 'Precarious' Non-Standard Employment - A Review of the Literature 'Precarious' NonStandard Employment - A Review of the Literature Abstract. Labour.

Midayati, N. (2018). Keadaan Ketenagakerjaan Indonesia Februari 2018. Berita Resmi Statistik. https://doi.org/No. 74/11/35/Th.XVI, 5 November 2018

Nafila, N., Kristine, E., \& Wijaya, E. (2017). Perlindungan Hak-Hak Buruh Pada Praktik Sistem Outsourcing: Sebuah Kesenjangan Penerimaan. Jurnal Hukum Novelty. https://doi.org/10.26555/novelty.v8i2.a5 552

Nastiti, A. D. (2017). Worker Unrest and Contentious Labor Practice of RideHailing Services in Indonesia. Arryman Symposium.

Nguyen, H.-C., Nguyen-Huu, T. T., Le Inwork, T.-T.-L., Nguyen-Huu, T., \& Le, T.-T.-L. (n.d.). Non-standard forms of employment in some Asian countries: A study of wages and working conditions of temporary workers. (69).

Quinlan, M. (2015). The effects of nonstandard forms of employment on worker health and safety. International Labour Organization.

Rabbani, D. R. (2019). Kerja Layak Bagi Mahasiswa Pekerja Kontrak Paruh Waktu (Garda Depan) Di PT. Aseli Dagadu Djokdja. Jurnal Studi Pemuda, $6(2)$, 605. https://doi.org/10.22146/studipemudaug m.39490

Saefuloh, A. A. (2011). Kebijakan Outsourcing di Indonesia: Perkembangan dan Permasalahan. Ekonomi \& Kebijakan Publik.

Sari, N. P. (2016). Transformasi Pekerja Informal ke Arah Formal: Analisis Deskriptif dan Regresi Logistik Informal Worker Transformation to Formal Sector: Descriptif and Logistic Regression Analyses. Jurnal Ekonomi 
Kuantitatif Terapan Vol. 9 No. 1.

Stewart, A., \& Stanford, J. (2017). Regulating work in the gig economy: What are the options? Economic and Labour Relations Review. https://doi.org/10.1177/1035304617722 461

Tjandraningsih, I. (2013). State-Sponsored Precarious Work in Indonesia. American Behavioral Scientist. https://doi.org/10.1177/0002764212466 236

Triani, K. W., \& Ariana, I. G. P. (2014). Perlindungan hukum terhadap pekerja paruh waktu apabila terjadi kecelakaan kerja. Kertha Semaya, 01(11), 1-5.

Triyono. (2011). Outsourcing Dalam Perspektif Pekerja Dan Pengusaha. PpkLipi. 